\title{
Activity-Dependent Reduction in Voltage-Dependent Calcium Current in a Crayfish Motoneuron
}

\author{
Sungwon J. Hong and Gregory A. Lnenicka \\ Neurobiology Research Center, Department of Biological Sciences, University at Albany, SUNY, Albany, New York \\ 12222
}

The effect of increased impulse activity upon voltage-dependent $\mathrm{Ca}^{2+}$ currents was studied in the cell body of a crayfish phasic motoneuron using two-electrode voltageclamp technique. Increased electrical activity in this relatively inactive motoneuron produces a short-term and longterm reduction in the voltage-dependent $\mathrm{Ca}^{2+}$ current. Both forms of activity-dependent reduction in $\mathrm{Ca}^{2+}$ current are $\mathrm{Ca}^{2+}$ dependent. The short-term reduction in $\mathrm{Ca}^{2+}$ current appears to involve the $\mathrm{Ca}^{2+}$-dependent inactivation of $\mathrm{Ca}^{2+}$ channels, previously described in a variety of neurons. The long-term reduction in $\mathrm{Ca}^{2+}$ current is produced by prolonged $\mathrm{Ca}^{2+}$ influx and persists for days: in vivo stimulation of the phasic motor axon at $5 \mathrm{~Hz}$ for $1 \mathrm{hr}$ results in a $30 \%$ reduction in $\mathrm{Ca}^{2+}$ current density, which persists for at least $3 \mathrm{~d}$. Both the short-term and long-term reductions in $\mathrm{Ca}^{2+}$ current appear to result from changes in a single type of high-voltage-activated (HVA) $\mathrm{Ca}^{2+}$ channel. Inhibition of protein synthesis attenuates the long-term reduction in $\mathrm{Ca}^{2+}$ current and has no effect upon the short-term $\mathrm{Ca}^{2+}$ current reduction. During the long-term reduction in $\mathrm{Ca}^{2+}$ current, it appears that $\mathrm{Ca}^{2+}$ channels located distant to the site of $\mathrm{Ca}^{2+}$ influx are affected. The relationship of these results to a previously described $\mathrm{Ca}^{2+}$-dependent reduction in transmitter release is discussed.

[Key words: activity, calcium channel, inactivation, protein synthesis, plasticity, motoneuron, crayfish, voltage clamp]

Calcium influx plays an important role in the short- and longterm regulation of neuronal structure and function. The relation ship between electrical activity and $\mathrm{Ca}^{2+}$ influx is largely determined by the properties of the neuron's voltage-dependent $\mathrm{Ca}^{2+}$ channels, and therefore the development and regulation of voltage-dependent $\mathrm{Ca}^{2+}$ channels is of considerable interest. Depolarization and $\mathrm{Ca}^{2+}$ influx have been shown to play a role in the regulation of voltage-dependent $\mathrm{Ca}^{2+}$ channels. In particular, a short-term $\mathrm{Ca}^{2+}$-dependent inactivation of voltage-dependent $\mathrm{Ca}^{2+}$ channels has been described in many vertebrate and invertebrate neurons (Tillotson, 1979; Lux and Brown, 1984; Chad and Eckert, 1986; Kay and Wong, 1987; Gutnick et al., 1989; Williams et al., 1991; Johnson and Byerly, 1993b; Fryer and

\footnotetext{
Received Aug. 26, 1994; revised Nov. 14, 1994; accepted Nov. 22, 1994.

This work was supported by a grant from the National Science Foundation (IBN9121757) to G.A.L.

Correspondence should be addressed to Gregory A. Lnenicka at the above address.

Copyright (C) 1995 Society for Neuroscience $0270-6474 / 95 / 153539-09 \$ 05.00 / 0$
}

Zucker, 1993). Although much less is known regarding the longterm effect of $\mathrm{Ca}^{2+}$ influx upon voltage-dependent $\mathrm{Ca}^{2+}$ channels, recent cell culture studies have shown that prolonged depolarization resulting from high extracellular potassium produces a long-term reduction in $\mathrm{Ca}^{2+}$ current density (Franklin et al., 1992; Berdan et al., 1993) and the number of $\mathrm{Ca}^{2+}$ channels (DeLorme and McGee, 1986; DeLorme et al., 1988). The reduction in the number of $\mathrm{Ca}^{2+}$ channels is $\mathrm{Ca}^{2+}$ dependent (DeLorme et al., 1988).

It is not known whether long-term, $\mathrm{Ca}^{2+}$-dependent changes in voltage-dependent $\mathrm{Ca}^{2+}$ channels are produced in situ by physiological stimulation. To determine this, we examined the effects of elevated impulse activity upon $\mathrm{Ca}^{2+}$ currents recorded from the cell body of a crayfish abdominal phasic motoneuron (F3). The normal impulse activity level of F3 is very low, allowing us to characterize $\mathrm{Ca}^{2+}$ channels under conditions of low impulse activity, and examine the short- and long-term effects of experimentally increasing impulse activity both in vitro and in vivo.

The effect of $\mathrm{Ca}^{2+}$ influx upon voltage-dependent $\mathrm{Ca}^{2+}$ channels in motoneuron $\mathrm{F} 3$ is of particular interest since we have recently demonstrated a long-term, $\mathrm{Ca}^{2+}$-dependent decrease in transmitter release from its motor terminals. Tonic stimulation of crustacean phasic motoneurons produces long-term changes in the physiology and morphology of the motor terminals, including a long-lasting decrease in transmitter release (for review see Lnenicka, 1991). This long-term, activity-dependent reduction in transmitter release has been reportcd for both vertcbratc and invertebrate motoneurons (Lnenicka and Atwood, 1985; Hinz and Wernig, 1988; Bradacs et al., 1990; Mercier and Atwood, 1990). We have shown that this reduction in transmitter release is $\mathrm{Ca}^{2+}$ dependent; that is, increased $\mathrm{Ca}^{2+}$ influx in the proximal region of $\mathrm{F} 3$ produces a long-term reduction in transmitter release from its motor terminals (Hong and Lnenicka, 1993a).

We report a $\mathrm{Ca}^{2+}$-dependent reduction in voltage-dependent $\mathrm{Ca}^{2+}$ current density that has two phases: a short-term reduction that appears similar to the previously described $\mathrm{Ca}^{2+}$-dependent inactivation of $\mathrm{Ca}^{2+}$ channels (Tillotson, 1979) and a long-term reduction that persists for at least $3 \mathrm{~d}$.

A preliminary report of these findings has appeared (Hong and Lnenicka, 1993b).

\section{Materials and Methods}

Preparation

Juvenile crayfish, Procambarus clarkii, with carapace lengths of 2-3 $\mathrm{cm}$ were used in these experiments. Crayfish were obtained from Atchafalaya Biological Supply (Raceland, LA). The third abdominal gan- 
glion was isolated and desheathed in van Harrevald's solution (van Harrevald, 1936) containing $1 \mathrm{mM}$ glucose and $10 \mathrm{~mm}$ HEPES ( $\mathrm{pH} 7.4$ ). Further details of the dissection and identification of the F3 soma have becn previously reported (Hong and Lnenicka, 1993a). All cxperiments were performed at $15^{\circ} \mathrm{C}$.

\section{Measurement of $\mathrm{Ca}^{2+}$ currents}

Conventional two-electrode voltage-clamp techniques were used for recording $\mathrm{Ca}^{2+}$ currents from the cell body of $\mathrm{F} 3$ using an Axoclamp-2A preamplifier (Axon Instruments Inc., Burlingame, CA). To block $\mathrm{Na}^{+}$ and $\mathrm{K}^{+}$currents, $1 \mu \mathrm{M}$ TTX, $50 \mathrm{~mm}$ TEA, and $1 \mathrm{mM}$ 4-AP were added to the saline. Changes in osmolarity were compensated by decreasing the concentration of $\mathrm{NaCl}$. To block $\mathrm{K}^{+}$currents further, the cell body was loaded with $\mathrm{Cs}^{+}$for 30-60 min using microelectrodes (5-10 $\mathrm{M} \Omega$ ) filled with $3 \mathrm{M} \mathrm{CsCl}$ (Tillotson, 1979; Gutnick et al., 1989). After blocking $\mathrm{Na}^{+}$and $\mathrm{K}^{+}$currents, the remaining inward current is carried by $\mathrm{Ca}^{2+}$. The application of the $\mathrm{Ca}^{2+}$ channel blockers, $10 \mathrm{mM} \mathrm{Co}{ }^{2+}$ or $6 \mathrm{mM} \mathrm{Mn}^{2+}$, blocks the remaining inward current completely (Hong and Lnenicka, 1993b). Data were acquired (sampling rate $5 \mathrm{kHz}$ ) and analyzed using VCAN V3.0 software and a DMA interface (LabMaster, Scientific Solutions Inc., Solon, $\mathrm{OH}$ ). The holding potential was set to -80 $\mathrm{mV}$ in most experiments. For some neurons, it was set to their resting membrane potentials of $-70--75 \mathrm{mV}$. $\Lambda \mathrm{ll}$ of the inward $\mathrm{Ca}^{2+}$ currents were corrected for linear leak currents by subtracting current produced by corresponding hyperpolarizing pulses. Calcium current density was determined by dividing the peak amplitude of $\mathrm{Ca}^{2}$ current by the membrane capacitance. Current-voltage $(I-V)$ curves were obtained by increasing depolarization in $10 \mathrm{mV}$ steps from the holding potential at 3 min intervals. Unless otherwise indicated, a paired Students $t$ test was used in all statistical comparisons.

\section{Stimulation}

In vitro stimulation. The effect of elevated impulse activity on the $\mathrm{Ca}^{2+}$ current was examined by stimulating $\mathrm{F} 3$ at $5 \mathrm{~Hz}$ for $30-45 \mathrm{~min}$. Stimulation pulses were delivered through a suction electrode placed against the F3 axon, and the impulse activity of F3 was monitored by intracellular recording from the axon (Fig. 1). Calcium currents were measured from the stimulated motoneuron 6-7 hr later and compared to those of the contralateral control motoneuron. In addition, to determine if $\mathrm{Ca}^{2+}$ influx is required for the reduction in $\mathrm{Ca}^{2+}$ current, $\mathrm{Ca}^{2+}$ influx during stimulation was blocked by applying $1 \mathrm{mM} \mathrm{Cd}^{2+}$ to the bath. To further minimize the possibility of $\mathrm{Ca}^{2+}$ influx during stimulation, the extracellular $\mathrm{Ca}^{2+}$ concentration was reduced to $5 \mathrm{~mm}$. (Extracellular $\mathrm{Ca}^{2+}$ concentrations less than $5 \mathrm{mM}$ frequently resulted in unstable resting membrane potentials.)

To examine the voltage-dependent $\mathrm{Ca}^{2+}$ currents during and immediately after stimulation, the cell was voltage clamped and stimulated with $50 \mathrm{msec}$ voltage steps to $0 \mathrm{mV}$ at 1 or $5 \mathrm{~Hz}$ for $10 \mathrm{~min}$. $\mathrm{Ca}^{2+}$ currents were measured during stimulation and at regular intervals for $1 \mathrm{hr}$ after stimulation. To examine the effect of $\mathrm{Ca}^{2+}$ influx on the reduction in the $\mathrm{Ca}^{2+}$ current, the amount of $\mathrm{Ca}^{2+}$ influx was altered by changing the extracellular $\mathrm{Ca}^{2+}$ concentration or changing the amplitude of the depolarizing pulses. Stimulation was performed in high $(2 \times$ normal, $27 \mathrm{~mm}$ ) extracellular $\mathrm{Ca}^{2+}$ with voltage steps to $0 \mathrm{mV}$, or in normal extracellular $\mathrm{Ca}^{2+}$ with voltage steps to $+35 \mathrm{mV}$. Changes in osmolarity of high $\mathrm{Ca}^{2+}(2 \times)$ saline were compensated by decreasing the $\mathrm{NaCl}$ concentration.

In vivo stimulation. To increase $\mathrm{F} 3$ impulse activity in vivo, crayfish were pinned with the ventral side up in a chamber filled with normal saline. After making a small slit along the midline of the third abdominal segment, a hook electrode was inserted through the slit and applied to the third root. Motoneuron F3 was stimulated at $5 \mathrm{~Hz}$ for approximately $1 \mathrm{hr}$; stimulation was applied for two 20-30 min periods separated by a 10-15 min rest. Activation of $F 3$ was continuously monitored by recording electromyograms with two pin electrodes positioned through the cuticle near muscle $A_{i i i}$ VIII (Rayner and Wiersma, 1965). In sham-operated animals, the electrodes were positioned as described but no stimulation was delivered. After stimulation, the animals were kept in an aquarium and $\mathrm{Ca}^{2+}$ currents were measured $3 \mathrm{~d}$ later.

\section{Double-pulse experiment}

The $\mathrm{Ca}^{2+}$-dependent inactivation of $\mathrm{Ca}^{2+}$ was examined with paired pulses delivered every $3 \mathrm{~min}$. The amplitude of the prepulse (P1) was increased by $10 \mathrm{mV}$ steps from the holding potential $(-80 \mathrm{mV})$ to +80

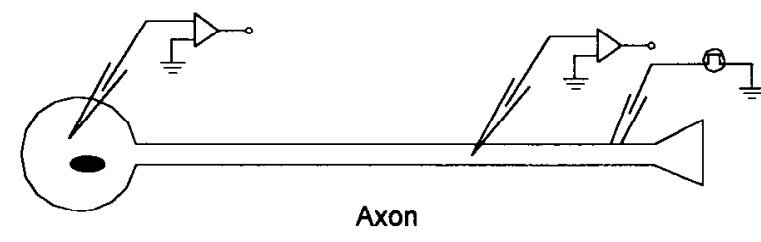

Cell body

Terminal

\section{$0 \mathrm{sec}$}

7 sec

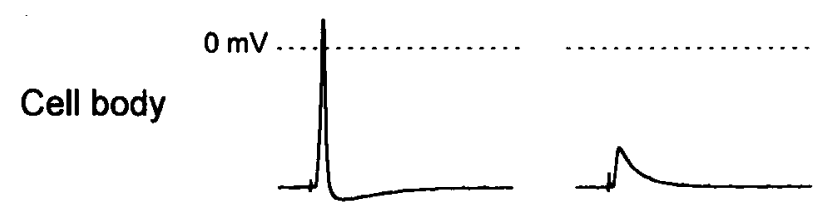

Axon
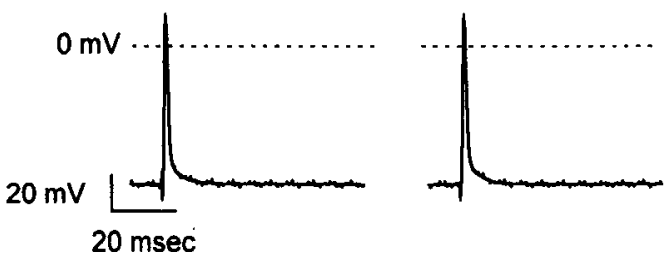

Figure 1. Stimulation of the phasic motoneuron, F3. Top, The axon was electrically stimulated with a suction electrode at $5 \mathrm{~Hz}$ for $30-45$ min. Suprathreshold stimulation of the axon was verified by recording action potentials from the axon with an intracellular electrode. Bottom, The upper panel shows the electrical activity recorded from the axon and cell body at the onset of stimulation $(0 \mathrm{sec})$ and $7 \mathrm{sec}$ later. Action potentials are generated in the cell body only during the first few seconds of stimulation, and afterward only an electrotonic potential is observed in the cell body.

$\mathrm{mV}$, whereas the peak amplitude of the subsequent test pulse (P2) was fixed at $0 \mathrm{mV}$ (see Fig. 6A). The double-pulse experiment was performed in normal $(13.5 \mathrm{~mm}) \mathrm{Ca}^{2+}$ or $13.5 \mathrm{~mm} \mathrm{Ba}{ }^{2+}\left(0 \mathrm{mM} \mathrm{Ca}^{2+}\right)$.

\section{Inhibition of protein synthesis}

The role of protein synthesis in the long-term reduction in voltagedependent $\mathrm{Ca}^{2+}$ currents was examined by applying the reversible protein synthesis inhibitor $0.6 \mathrm{~mm}$ cycloheximide (CHX) (Boehringer Mannheim Corp. Indianapolis, IN) to the bath $4-5 \mathrm{hr}$ prior to in vitro stimulation. CHX (0.6 mM) has been shown to produce a $90 \%$ block of protein synthesis and no immediate effect on neuromuscular transmission in the crayfish (Nguyen and Atwood, 1990). To examine the effect of CHX upon the short-tern reduction in $\mathbf{C a}^{2+}$ currents, stinulation $(50 \mathrm{msec}$ voltage steps to $0 \mathrm{mV}$ at $1 \mathrm{~Hz}$ for $10 \mathrm{~min}$ ) was performed in the presence of $\mathrm{CHX}$. To examine the effect of $\mathrm{CHX}$ upon the long-term reduction in $\mathrm{Ca}^{2+}$ current, the axon of $\mathrm{F} 3$ was electrically stimulated at $5 \mathrm{~Hz}$ for $45 \mathrm{~min}$ in vitro in the presence of $\mathrm{CHX}$. After stimulation, $\mathrm{CHX}$ was washed out and the preparation was maintained in normal saline. The $\mathrm{Ca}^{2+}$ currents were measured 6-7 hr after stimulation.

\section{Results}

Activity-dependent reduction in voltage-dependent $\mathrm{Ca}^{2+}$ current

To examine the effect of increased impulse activity upon the voltage-dependent $\mathrm{Ca}^{2+}$ current, the relatively silent motoneuron F3 was electrically stimulated in vitro (Fig. 1, top). The third 

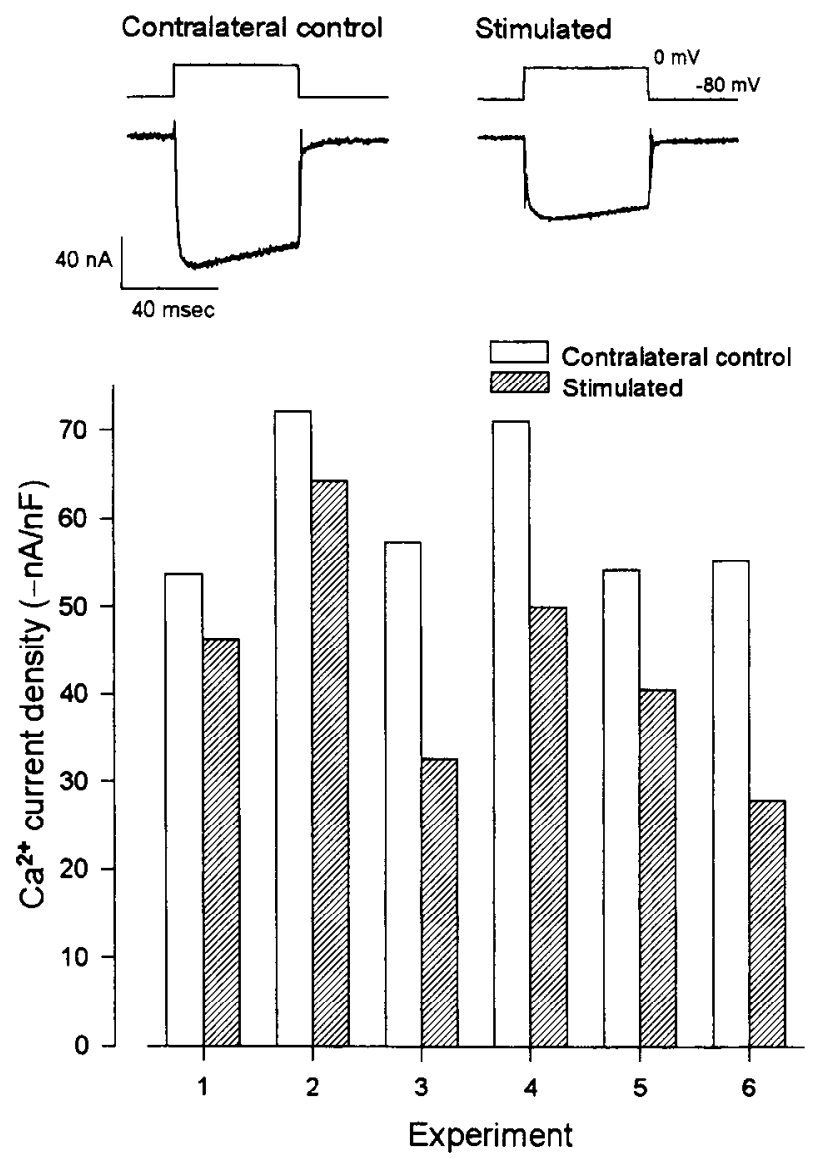

Figure 2. Increased impulse activity produces a long-term reduction in $\mathrm{Ca}^{2+}$ current density. The peak $\mathrm{Ca}^{2+}$ current was measured in stimulated and contralateral control cell bodies $6-7 \mathrm{hr}$ after stimulation. Top, Both stimulated and contralateral control cell bodies were voltage clamped and the peak $\mathrm{Ca}^{2+}$ current was recorded during step depolarizations to $0 \mathrm{mV}$. Bottom, In all six experiments, the stimulated cell body had a smaller $\mathrm{Ca}^{2+}$ current density than the contralateral control. The $\mathrm{Ca}^{2+}$ current density was significantly less in stimulated $(-43.6 \pm 5.3$ $\mathrm{nA} / \mathrm{nF})$ compared to contralateral control cells $(-60.6 \pm 3.5 \mathrm{nA} / \mathrm{nF}, n$ $=6 ; p<0.01$ ).

abdominal ganglion was isolated along with the fast flexor musculature. The $\mathrm{F} 3$ axon was stimulated at $5 \mathrm{~Hz}$ for $30-45 \mathrm{~min}$, producing a substantial increase in normal impulse activity. Figure 1 (bottom) shows the electrical activity in the axon and cell body produced by suprathreshold electrical stimulation. The axon produces action potentials throughout the period of stimulation. However, after 30-50 stimulations the cell body fails to produce action potentials, leaving only an electrotonic depolarization of approximately $20 \mathrm{mV}$.

The effect of increased impulse activity was examined 6-7 hr after stimulation by measuring the amplitude of the peak $\mathrm{Ca}^{2+}$ current during depolarizing voltage steps to $0 \mathrm{mV}$ in stimulated and contralateral control cell bodies (Fig. 2, top). In every experiment, the density of the peak $\mathrm{Ca}^{2+}$ current was less in the stimulated cell than the contralateral control cell (Fig. 2, bottom). The mean density of the voltage-dependent $\mathrm{Ca}^{2+}$ current was $28.7 \pm 6.3 \%$ less in the stimulated cell bodies $(-43.6 \pm$ $5.3 \mathrm{nA} / \mathrm{nF}$ ) compared to the contralateral control cell bodies $(-60.6 \pm 3.5 \mathrm{nA} / \mathrm{nF}, n=6 ; p<0.01)$. These results demonstrate that the increased impulse activity results in a decrease in the peak amplitude of the voltage-dependent $\mathrm{Ca}^{2+}$ current recorded from the cell body.

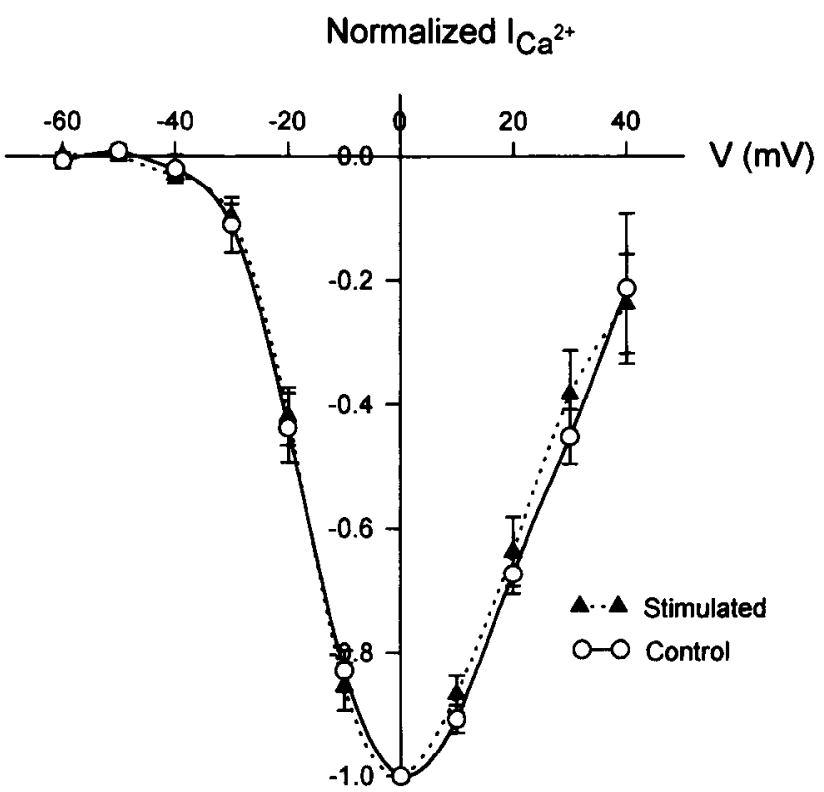

Figure 3. The long-term reduction in the $\mathrm{Ca}^{2+}$ current occurs in the absence of changes in the voltage dependence of the $\mathrm{Ca}^{2+}$ channels. I$V$ curves for stimulated and control motoneurons were compared. The $I-V$ curves were normalized and mean values were obtained for nine stimulated and 12 control motoneurons. The $I-V$ curves for the stimulated and control motoneurons are very similar. Thus, while the $\mathrm{Ca}^{2+}$ current density decreases as a result of stimulation, there is no change in the voltage dependence of the individual $\mathrm{Ca}^{2+}$ channels.

This reduction in $\mathrm{Ca}^{2+}$ current does not appear to involve changes in the voltage dependence or kinetics of the $\mathrm{Ca}^{2+}$ channels. The voltage-dependent $\mathrm{Ca}^{2+}$ conductance in this cell body appears to be dominated by a single class of $\mathrm{HVA} \mathrm{Ca}^{2+}$ channels (S. J. Hong and G. A. Lnenicka, unpublished observations). The decrease in $\mathrm{Ca}^{2+}$ conductance occurs without a change in the voltage dependence of the $\mathrm{Ca}^{2+}$ channel since the normalized I$V$ curves from stimulated and contralateral control cells are identical (Fig. 3). The kinetics of the $\mathrm{Ca}^{2+}$ current decay during the pulse are not altered by stimulation since the decay follows a single exponential curve with a similar time constant $(\tau)$ in both control $(215 \pm 13 \mathrm{msec}, n=6)$ and stimulated cells (206 \pm $10 \mathrm{msec}, n=6)$.

\section{Long-term reduction in $\mathrm{Ca}^{2+}$ current persists for days}

To examine the duration of this activity-dependent reduction in $\mathrm{Ca}^{2+}$ current, the motoneuron was stimulated in vivo and the $\mathrm{Ca}^{2}$ current was measured $3 \mathrm{~d}$ later. As previously described (see Materials and Methods), the third root was electrically stimulated at $5 \mathrm{~Hz}$ for approximately $1 \mathrm{hr}$ with a hook electrode, and activation of $\mathrm{F} 3$ was verified by recording electromyograms from muscle $A_{i i i}$ VIII. Three days later, the $\mathrm{Ca}^{2+}$ current was measured in the cell bodies of stimulated motoneurons and sham-operated control motoneurons (Fig. 4). The mean $\mathrm{Ca}^{2+}$ current density of stimulated cells $(-40.8 \pm 3.5 \mathrm{nA} / \mathrm{nF}, n=7)$ was significantly less than that of sham-operated controls $(-57.0$ $\pm 2.4 \mathrm{nA} / \mathrm{nF}, n=5 ; t$ test, $p<0.01$ ). The procedure used for in vivo stimulation had no direct effect upon the $\mathrm{Ca}^{2+}$ currents since the $\mathrm{Ca}^{2+}$ current density of sham-operated controls was not significantly different from that of normal animals $(-59.9 \pm$ $2.0 \mathrm{nA} / \mathrm{nF}, n=32 ; t$ test, $p>0.1)$. The percent reduction in $\mathrm{Ca}^{2+}$ current density $(31.9 \pm 5.8 \%, n=7) 3 \mathrm{~d}$ after in vivo stimulation was similar to that observed 6-7 hr after in vitro 


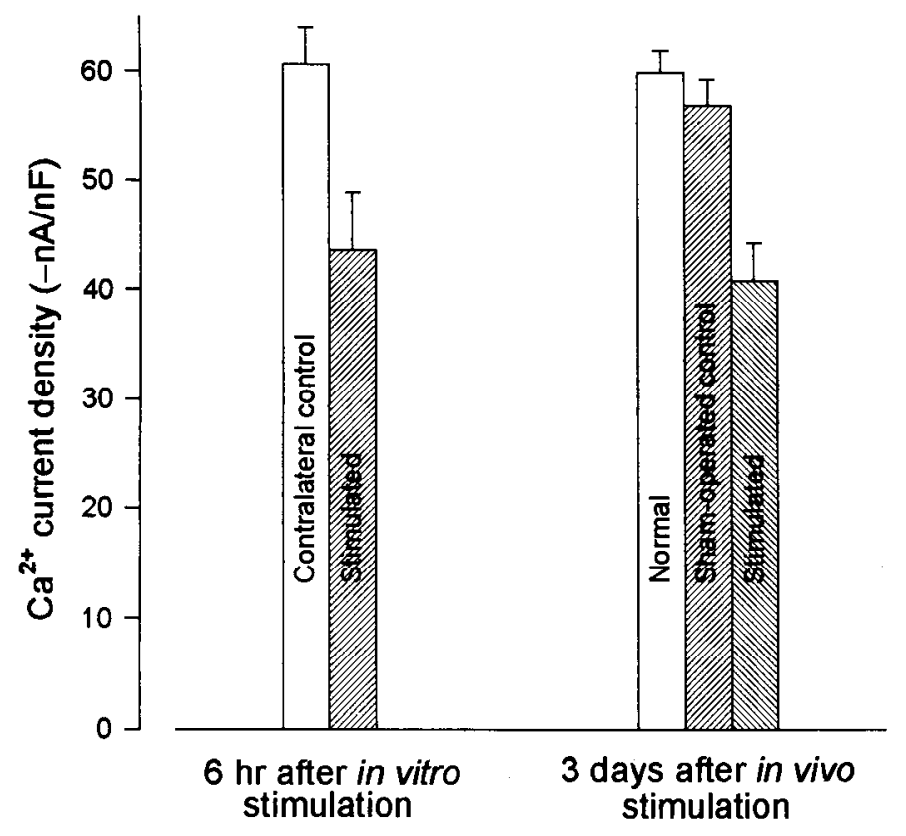

Figure 4. The long-term reduction in $\mathrm{Ca}^{2+}$ current lasts for days. The F3 axon was electrically stimulated in vivo at $5 \mathrm{~Hz}$ for approximately $1 \mathrm{hr}$. Three days later, the $\mathrm{Ca}^{2+}$ current was measured in the stimulated and the sham-operated control cells. The $\mathrm{Ca}^{2+}$ current density was significantly less in the stimulated $\mathrm{F} 3$ motoneurons $(-40.8 \pm 3.5 \mathrm{nA} / \mathrm{nF}$, $n=7$ ) compared to measurements from the sham-operated control motoneurons $(-57.0 \pm 2.4 \mathrm{nA} / \mathrm{nF}, n=5 ; t$ test, $p<0.01)$. There was no significant difference between the $\mathrm{Ca}^{2+}$ current densities of $\mathrm{F} 3$ motoneurons in sham-operated controls and normal animals $(-59.9 \pm 2.0$ $\mathrm{nA} / \mathrm{nF}, n=32 ; t$ test, $p>0.1$ ). These values are compared to the previous experiment where measurements were performed 6-7 hr after stimulation. The $31.9 \pm 5.8 \%(n=7)$ reduction in $\mathrm{Ca}^{2+}$ current density observed $3 \mathrm{~d}$ after in vivo stimulation is similar to the $28.7 \pm 6.3 \%$ ( $n$ $=6$ ) reduction observed $6-7 \mathrm{hr}$ after in vitro stimulation. Thus, the effect of stimulation lasts for $3 \mathrm{~d}$ with no decline.

stimulation $(28.7 \pm 6.3 \%, n=6)$. Thus, the effect of stimulation shows no attenuation after $3 \mathrm{~d}$. In addition, there was no change in the shape of the $I-V$ curve for the $\mathrm{Ca}^{2+}$ current after in vivo stimulation.

\section{Reduction in $\mathrm{Ca}^{2+}$ current during stimulation}

To examine further the activity-dependent reduction in $\mathrm{Ca}^{2+}$ current, $\mathrm{Ca}^{2+}$ current was measured during stimulation. The cell body was voltage clamped and repetitive $50 \mathrm{msec}$ voltage steps to $0 \mathrm{mV}$ were applied at 1 or $5 \mathrm{~Hz}$ for $10 \mathrm{~min}$. Sodium and potassium currents were blocked during stimulation to allow the measurement of the $\mathrm{Ca}^{2+}$ current. During repetitive stimulation, there is a rapid, short-term decrease in $\mathrm{Ca}^{2+}$ currents: the peak $\mathrm{Ca}^{2+}$ current was reduced by approximately $66 \%$ at the end of $1 \mathrm{~Hz}$ stimulation and by approximately $96 \%$ at the end of $5 \mathrm{~Hz}$ stimulation (Fig. 5). After stimulation, there is an initial rapid recovery of the $\mathrm{Ca}^{2+}$ current, followed by a slower recovery. One hour after $1 \mathrm{~Hz}$ stimulation the recovery is almost complete, but there remains a significant $6.7 \pm 2.8 \%$ reduction in $\mathrm{Ca}^{2+}$ current $(n=4 ; p<0.05)$. This persistent reduction is particularly evident after $5 \mathrm{~Hz}$ stimulation: there is a significant 30.4 $\pm 8.4 \%(n=7 ; p<0.05)$ decrease in the peak $\mathrm{Ca}^{2+}$ current 1 hr after stimulation. This reduction in $\mathrm{Ca}^{2+}$ current occurs in the absence of any change in the shape of the $I-V$ curve.

These results demonstrate that depolarizing pulses applied to the cell body produce a rapid, short-term reduction in $\mathrm{Ca}^{2+}$ cur-

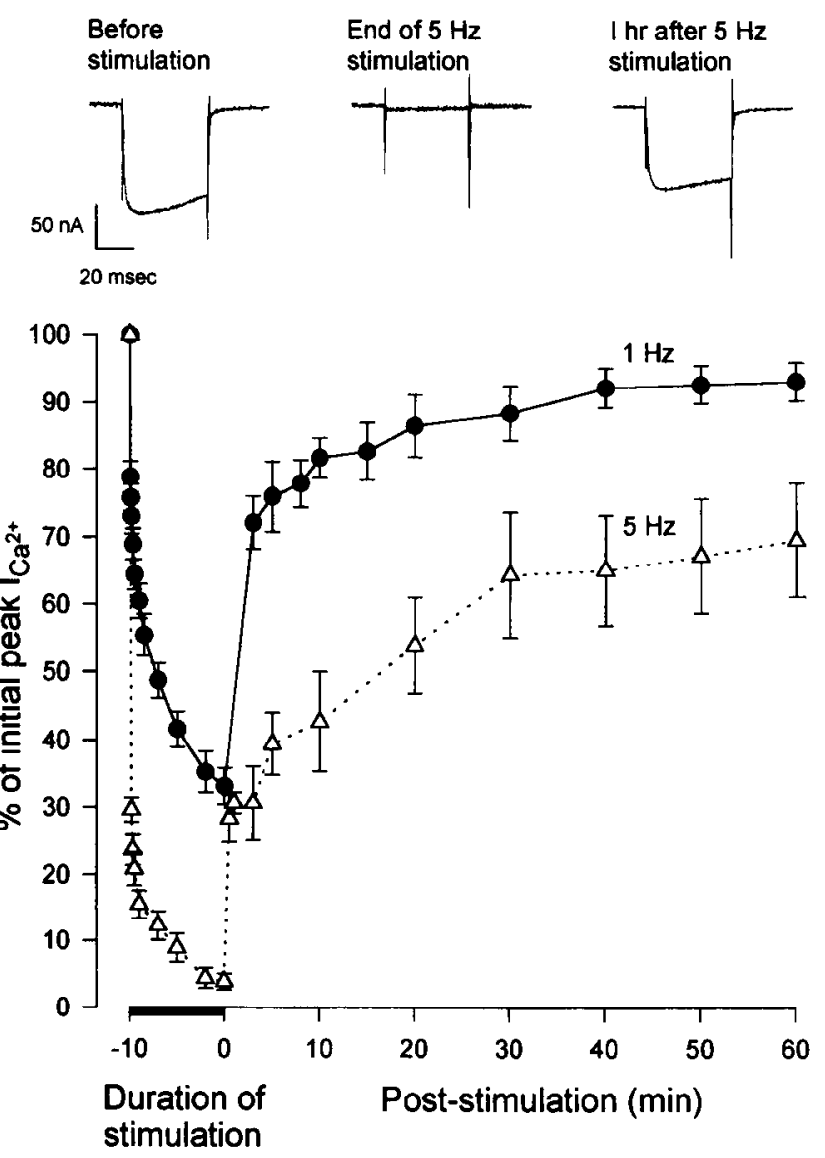

Figure 5. A rapid, short-term reduction in $\mathrm{Ca}^{2+}$ current occurs during stimulation. The cell body was voltage clamped and repetitive $50 \mathrm{msec}$ depolarizing pulses to $0 \mathrm{mV}$ were applied. The depolarizing pulses were applied at 1 and $5 \mathrm{~Hz}$ and the peak $\mathrm{Ca}^{2+}$ currents were measured during stimulation and at regular intervals for $1 \mathrm{hr}$ after stimulation. The $\mathrm{Ca}^{2+}$ currents were normalized to the initial $\mathrm{Ca}^{2+}$ current measured at the onset of stimulation. The $\mathrm{Ca}^{2+}$ current depressed rapidly during stimulation. After stimulation, there was an initial rapid recovery, followed by a more gradual recovery. At both stimulation frequencies, there was a persistent reduction in the $\mathrm{Ca}^{2+}$ current that was observed $1 \mathrm{hr}$ after stimulation. Insert, Representative $\mathrm{Ca}^{2+}$ currents measured before $5 \mathrm{~Hz}$ stimulation, at the end of stimulation, and $1 \mathrm{hr}$ after stimulation.

rent that recovers immediately after the end of stimulation along with a more persistent reduction in $\mathrm{Ca}^{2+}$ current. It is unclear whether this persistent reduction is the same as the long-term reduction in $\mathrm{Ca}^{2+}$ current that lasts for days. Both of these effects are produced in the absence of sodium influx.

\section{Short-term reduction in $\mathrm{Ca}^{2+}$ current is $\mathrm{Ca}^{2+}$ dependent}

A $\mathrm{Ca}^{2+}$-dependent inactivation of $\mathrm{Ca}^{2+}$ channels has been described in a number of vertebrate and invertebrate neurons (for review see Eckert and Chad, 1984; Chad, 1989). To determine if the short-term reduction in $\mathrm{Ca}^{2+}$ current observed during repetitive stimulation is due to $\mathrm{Ca}^{2+}$-dependent inactivation of $\mathrm{Ca}^{2+}$ channels, the relationship between $\mathrm{Ca}^{2+}$ entry and $\mathrm{Ca}^{2+}$ current inactivation was examined. $\Lambda \mathrm{s}$ in a previous study (Tillotson, 1979), paired pulses were applied under voltage-clamp conditions to determine the effect of prior $\mathrm{Ca}^{2+}$ entry upon $\mathrm{Ca}^{2+}$ current (Fig. 6A). It was found that the inactivation of the $\mathrm{Ca}^{2+}$ current was dependent upon the amount of $\mathrm{Ca}^{2+}$ entry and not membrane voltage (Fig. $6 \mathrm{~B}$ ). There was a strong correlation between the peak amplitude of the $\mathrm{Ca}^{2+}$ current during the first 
A.

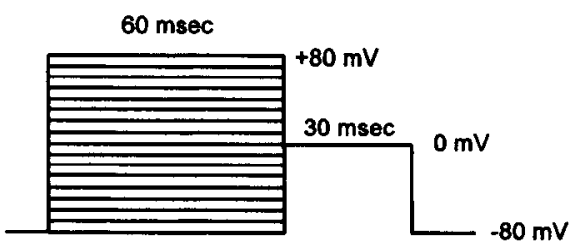

P1

P2

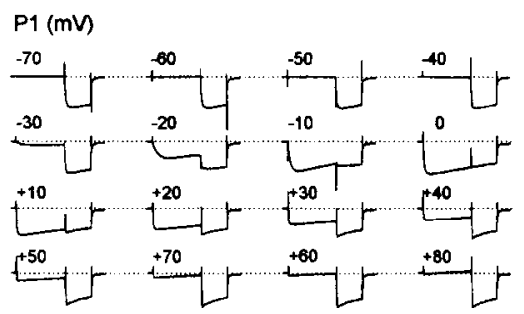

B.

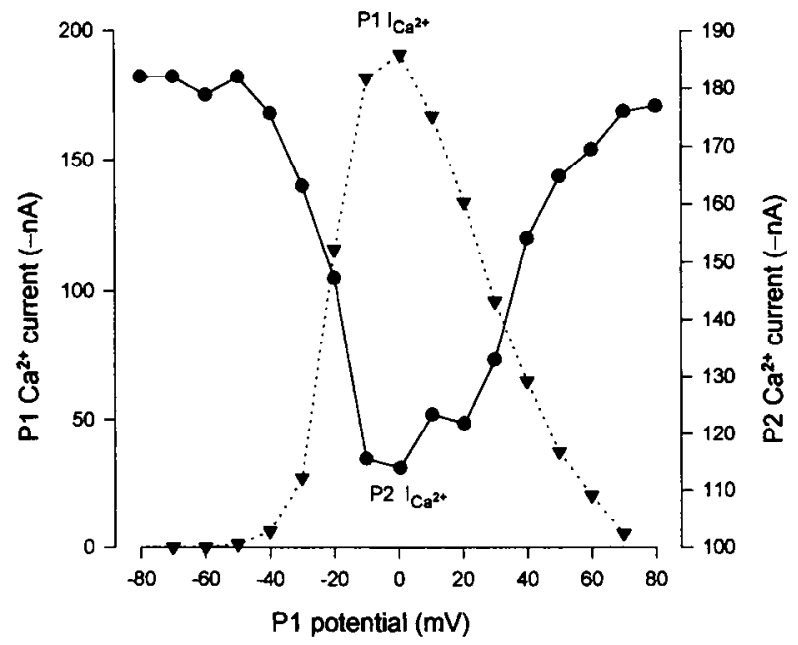

C.

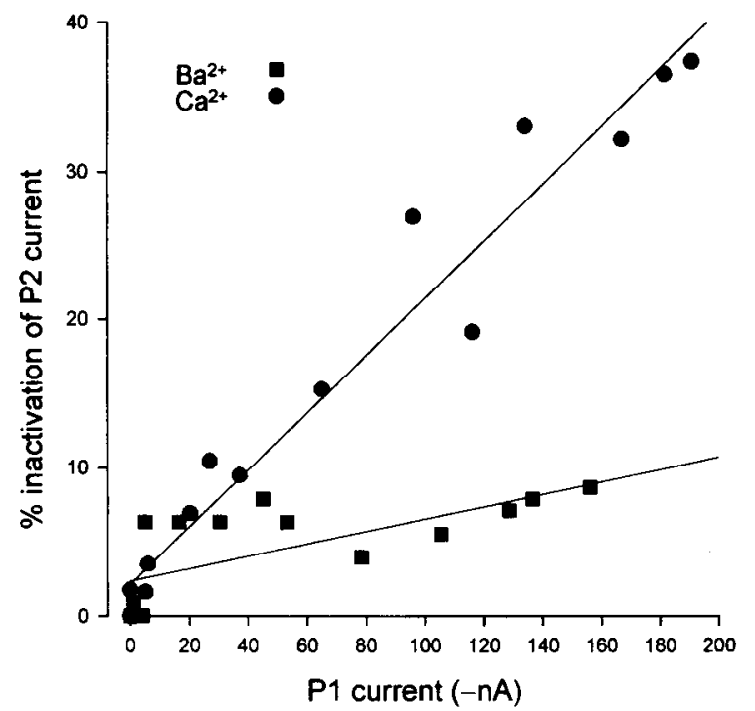

Figure 6. Calcium-dependent inactivation of $\mathrm{Ca}^{2+}$ channels. $A$, To determine whether these $\mathrm{Ca}^{2+}$ channels show $\mathrm{Ca}^{2+}$-dependent inactivation, pulsc and the percent inactivation of the $\mathrm{Ca}^{2+}$ current during the second pulse (Fig. 6C): there was approximately $40 \%(n=3)$ inactivation of $\mathrm{P} 2 \mathrm{Ca}^{2+}$ current when $\mathrm{Pl} \mathrm{Ca}^{2+}$ current was maximal. This is consistent with previous double-pulse studies of $\mathrm{Ca}^{2+}$-dependent $\mathrm{Ca}^{2+}$ channel inactivation (Brehm and Eckert, 1978; Tillotson, 1979; Eckert and Tillotson, 1981; Gutnick et al., 1989; Fryer and Zucker, 1993). In addition, very little $\mathrm{Ca}^{2+}$ channel inactivation was seen when $\mathrm{Ca}^{21}$ was replaced with $\mathrm{Ba}^{2+}$ (Fig. 6C). This is consistent with previous findings that $\mathrm{Ba}^{2+}$ is permeable through $\mathrm{Ca}^{2+}$ channels, but produces little $\mathrm{Ca}^{2+}$ channel inactivation (Brehm and Eckert, 1978; Tillotson, 1979). All these results agree with the criteria of $\mathrm{Ca}^{2+}$-dependent inactivation of $\mathrm{Ca}^{2+}$ channels (for review see Chad, 1989).

To determine directly whether the short-term reduction in $\mathrm{Ca}^{2+}$ current during repetitive stimulation is $\mathrm{Ca}^{2+}$ dependent, $\mathrm{Ca}^{2+}$ entry during repetitive stimulation was altered. In the previous experiment, repetitive $50 \mathrm{msec}$ voltage steps to $0 \mathrm{mV}$ were applied at $1 \mathrm{~Hz}$ for $10 \mathrm{~min}$ (Fig. 5). To alter $\mathrm{Ca}^{2+}$ entry, stimulation was performed in $2 \times$ normal $\mathrm{Ca}^{2+}$ concentration $(27$ $\mathrm{mM}$ ) with voltage steps to $0 \mathrm{mV}$, or in normal $\mathrm{Ca}^{2+}$ concentration with voltage steps to $+35 \mathrm{mV}$. Compared to the earlier experiment, the initial $\mathrm{Ca}^{2+}$ current before stimulation was increased by $12 \%$ in $2 \times$ normal $\mathrm{Ca}^{2+}$ and was decreased by $72 \%$ by applying pulses to $+35 \mathrm{mV}$ (Fig. $7 A$ ). In the previous experiment, $1 \mathrm{~Hz}$ stimulation in normal $\mathrm{Ca}^{2+}$ concentration resulted in approximately a $66 \%$ reduction in $\mathrm{Ca}^{2+}$ current at the end of stimulation and a $7 \%$ reduction in $\mathrm{Ca}^{2+}$ current $1 \mathrm{hr}$ after stimulation. As shown in Figure $7 A$, stimulation in $2 \times \mathrm{Ca}^{2+}$ resulted in a $70.3 \pm 2.7 \%(n=6)$ reduction in the $\mathrm{Ca}^{2+}$ current at the end of stimulation and a $21.9 \pm 2.6 \%(n=6)$ reduction 1 hr poststimulation. Stimulation with depolarizing pulses to $+35 \mathrm{mV}$ produced a dramatic decrease in the reduction in $\mathrm{Ca}^{2+}$ current during stimulation, resulting in only a $34.8 \pm 5.7 \%(n=5)$ reduction at the end of stimulation, which recovered rapidly. The $\mathrm{Ca}^{2+}$ current totally recovered to its original value within $40 \mathrm{~min}$ after the end of stimulation.

These results demonstrate that the short-term reduction in $\mathrm{Ca}^{2+}$ current observed during repetitive stimulation is $\mathrm{Ca}^{2+}$ dependent and appears to result from the previously described $\mathrm{Ca}^{2+}$-dependent inactivation of $\mathrm{Ca}^{2+}$ channels. The persistent reduction in $\mathrm{Ca}^{2+}$ current observed $1 \mathrm{hr}$ after stimulation is also

\section{$\leftarrow$}

paired voltage-clamp pulses were applied to the cell body. The amplitude of a prepulse $(P I)$ was varied, while the amplitude of the subsequent test pulse $(P 2)$ amplitude remained constant. The paired pulses were delivered at 3 min intervals. An increase in amplitude of the $\mathrm{Ca}^{2+}$ current during $\mathrm{P} 1$ resulted in a decrease in the $\mathrm{Ca}^{2+}$ current during P2. $B$, To examine the relationship between $\mathrm{P} 1$ membrane potential, $\mathrm{P} 1 \mathrm{Ca}^{2+}$ current, and $\mathrm{P} 2 \mathrm{Ca}^{2+}$ current, the $\mathrm{Ca}^{2+}$ currents during $\mathrm{P} 1(\boldsymbol{\nabla})$ and $\mathrm{P} 2$ (O) are plotted against $\mathrm{P} 1$ membrane potential. The $\mathrm{P} 2 \mathrm{Ca}^{2+}$ current was minimal when the $\mathrm{P} 1 \mathrm{Ca}^{2+}$ current was maximal. The $\mathrm{P} 2 \mathrm{Ca}^{2+}$ current was not dependent upon the membrane potential during P1. $C$, To examine further the relationship between $\mathbf{P} 1 \mathrm{Ca}^{2+}$ influx and the amount of inactivation of the $\mathrm{P} 2 \mathrm{Ca}^{2+}$ current, the percent inactivation of the $\mathrm{P} 2 \mathrm{Ca}^{2+}$ current $\left[\%\right.$ inactivation $=100 \times\left(\mathrm{P} 2 I_{\mathrm{Ca}}\right.$ with no $\mathrm{P} 1$ pulse - $\left.\mathrm{P} 2 I_{\mathrm{Ca}}\right) / \mathrm{P} 2 I_{\mathrm{Ca}}$ with no $\mathrm{P} 1$ pulse] was plotted against the peak amplitude of the $\mathrm{PI} \mathrm{Ca}{ }^{2+}$ current. The percent inactivation of the $\mathrm{P} 2$ $\mathrm{Ca}^{2+}$ current $(\mathrm{O})$ is strongly correlated with the amplitude of the P1 $\mathrm{Ca}^{2+}$ current $\left(r^{2}=0.96\right)$. To confirm that the inactivation of $\mathrm{Ca}^{2+}$ current is dependent on $\mathrm{Ca}^{2+}$ entry, the effect of substituting $\mathrm{Ba}^{2+}$ for $\mathrm{Ca}^{2+}$ was examined. The $\mathrm{Ba}^{2+}$ currents during P2 ( $\left.\boldsymbol{\square}\right)$ showed much less inactivation than the $\mathrm{Ca}^{2+}$ currents. The correlation between the $\mathrm{P} 1$ current and the inactivation of the $\mathrm{P} 2$ current is weaker for $\mathrm{Ba}^{2+}\left(r^{2}=0.45\right)$ than for $\mathrm{Ca}^{2+}$. 
A.

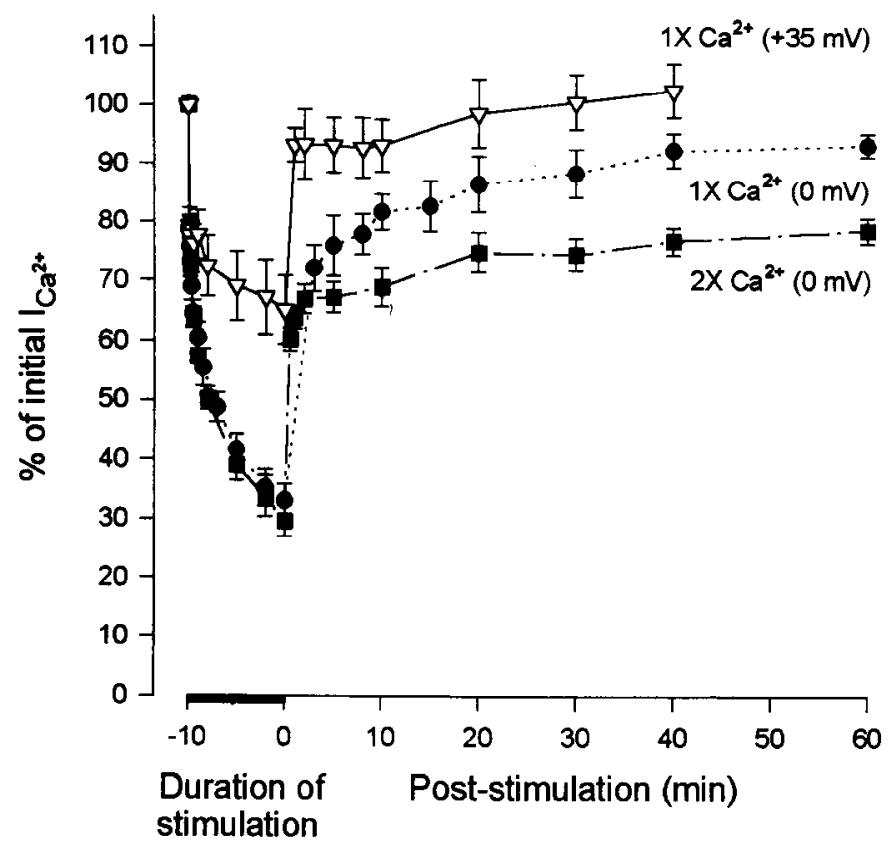

B.

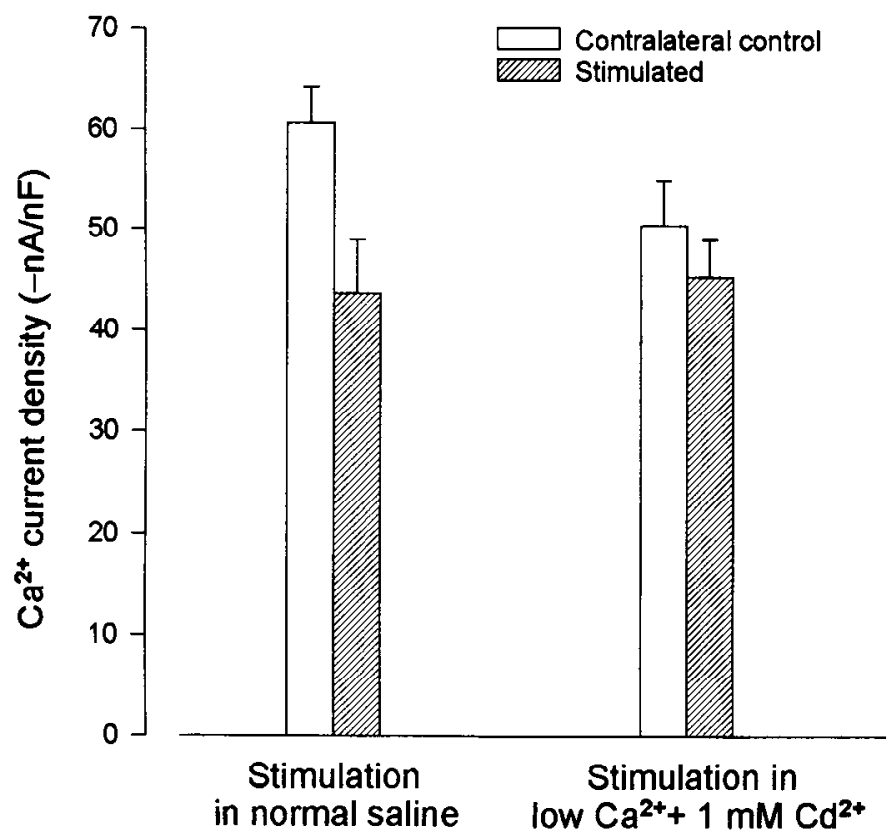

Figure 7. Both the short-term and long-term reductions in $\mathrm{Ca}^{2+}$ current are $\mathrm{Ca}^{2+}$ dependent. $A$, To determine whether the short-term reduction in $\mathrm{Ca}^{2+}$ current was $\mathrm{Ca}^{++}$dependent, the cell body was stimulated by delivering $50 \mathrm{msec}$ depolarizing voltage steps to $0 \mathrm{mV}$ at $1 \mathrm{~Hz}$ for $10 \mathrm{~min}$ in $2 \times$ normal $(27 \mathrm{mM}) \mathrm{Ca}^{2+}$ concentration or by delivering $50 \mathrm{msec}$ depolarizing voltage steps to $+35 \mathrm{mV}$ in normal $\mathrm{Ca}^{2+}$. These results were compared to the previous experiment in which the cell body was stimulated with depolarizing steps to $0 \mathrm{mV}$ in normal $\mathrm{Ca}^{2+}$ (Fig. 5). The peak $\mathrm{Ca}^{2+}$ currents were measured during stimulation and at regular intervals for $1 \mathrm{hr}$ after stimulation, and normalized to the initial $\mathrm{Ca}^{2+}$ current: $-33.6 \pm 7.2 \mathrm{nA}(n=5)$ for $1 \times \mathrm{Ca}^{2+}$ saline $(+35 \mathrm{mV})$, $-119.8 \pm 6.3 \mathrm{nA}(n=4)$ for $1 \times \mathrm{Ca}^{2+}$ saline $(0 \mathrm{mV})$, and $-133.5 \pm$ $8.6 \mathrm{nA}(n=6)$ for $2 \times \mathrm{Ca}^{2+}$ saline $(0 \mathrm{mV})$. In $2 \times \mathrm{Ca}^{2+}(0 \mathrm{mV})$ the
$\mathrm{Ca}^{2+}$ dependent. It is increased with greater $\mathrm{Ca}^{2+}$ influx and is totally eliminated when $\mathrm{Ca}^{2+}$ influx is reduced.

\section{Long-term reduction in $\mathrm{Ca}^{2+}$ current is $\mathrm{Ca}^{2+}$ dependent}

To examine the role of $\mathrm{Ca}^{2+}$ in the long-term reduction in $\mathrm{Ca}^{2+}$ current, the effect of $\mathrm{Ca}^{2+}$ influx upon the reduction in $\mathrm{Ca}^{2+}$ current observed 6-7 hr after stimulation was examined. In these experiments, $\mathrm{Ca}^{2+}$ influx during stimulation was blocked by applying an inorganic $\mathrm{Ca}^{2+}$ channel blocker, $1 \mathrm{mM} \mathrm{Cd}^{2+}$, and reducing the $\mathrm{Ca}^{2+}$ concentration (see Materials and Methods). As in the previous experiment (Fig. 2), the axon was stimulated at $5 \mathrm{~Hz}$ for 30-45 min. After stimulation, the cell was maintained in normal saline for 6-7 hr until $\mathrm{Ca}^{2+}$ currents were measured in stimulated and contralateral control motoneurons (Fig. 7B). The $\mathrm{Ca}^{2+}$ current density of the stimulated neuron $(-45.3 \pm$ $3.7 \mathrm{nA} / \mathrm{nF}$ ) was not significantly different from that of the contralatcral control neuron ( $50.4 \pm 4.5 \mathrm{nA} / \mathrm{nF}, n=5 ; p>0.1$ ). The values for the $\mathrm{Ca}^{2+}$ current in the control motoneuron are less (approximately 17\%) than in the previous experiments. It is unclear whether this is due to interanimal variability or incomplete removal of the $\mathrm{Cd}^{2+}$. Nonetheless, the results demonstrate that the long-term reduction in $\mathrm{Ca}^{2+}$ current is $\mathrm{Ca}^{2+}$ dependent since blocking $\mathrm{Ca}^{2+}$ influx during stimulation prevented the reduction in $\mathrm{Ca}^{2+}$ current.

\section{Effect of inhibition of protein synthesis}

In a previous study, it was shown that application of CHX 2-6 $\mathrm{hr}$ before stimulation of a crayfish phasic motoneuron attenuated the long-term, activity-dependent reduction in transmitter release from the motor terminals (Nguyen and Atwood, 1990). To determine whether the long-term reduction in $\mathrm{Ca}^{2+}$ current has a similar requirement for protein synthesis, $0.6 \mathrm{mM} \mathrm{CHX}$, a reversible translational inhibitor (Wettstein et al., 1964), was added to the bath 4-5 hr before stimulation. We first examined the effect of protein synthesis inhibition upon the short-term reduction in $\mathrm{Ca}^{2+}$ current produced during repetitive $50 \mathrm{msec}$ voltage steps to $0 \mathrm{mV}$ delivered at $1 \mathrm{~Hz}$ for $10 \mathrm{~min}$. Stimulation was performed in $2 \times$ normal $\mathrm{Ca}^{2+}$ concentration to produce a greater reduction in $\mathrm{Ca}^{2+}$ current. Inhibition of protein synthesis had no

$\leftarrow$

initial $\mathrm{Ca}^{2+}$ current was $12 \%$ greater than in the previous experiment, $1 \times \mathrm{Ca}^{2+}(0 \mathrm{mV})$. The slightly greater $\mathrm{Ca}^{2+}$ influx appeared to produce only a small increase in the $\mathrm{Ca}^{2+}$ current reduction during stimulation; however, there was a substantial increase in the persistent reduction in $\mathrm{Ca}^{2+}$ observed $1 \mathrm{hr}$ after stimulation $(21.9 \pm 2.6 \%, n=6 ; p<0.05)$. Stimulation with voltage steps to $+35 \mathrm{mV}$ decreased the initial $\mathrm{Ca}^{2+}$ current amplitude by $72 \%$ and produced a substantial decrease in the $\mathrm{Ca}^{2+}$ current reduction during repetitive stimulation. There was a 34.8 $\pm 5.7 \%(n=5)$ reduction in $\mathrm{Ca}^{2+}$ current at the end of $10 \mathrm{~min}$ stimulation and the $\mathrm{Ca}^{2+}$ current was fully recovered 40 min after stimulation $(102.6 \pm 4.5 \%, n=5 ; p>0.1)$. Thus, the short-term reduction in $\mathrm{Ca}^{2+}$ current during repetitive stimulation is dependent on the amount of $\mathrm{Ca}^{2+}$ influx. $B$, To examine whether the long-term reduction in $\mathrm{Ca}^{2+}$ current is $\mathrm{Ca}^{2+}$ dependent, the $\mathrm{Ca}^{2+}$ influx during stimulation was blocked by applying an inorganic $\mathrm{Ca}^{2+}$ channel blocker, $1 \mathrm{mM} \mathrm{Cd}^{2+}$, to low $(5 \mathrm{~mm}) \mathrm{Ca}^{2+}$ saline. The $\mathrm{F} 3$ axon was stimulated at $5 \mathrm{~Hz}$ for 30 $45 \mathrm{~min}$ as previously described. After stimulation, $\mathrm{Cd}^{2+}$ was washed out and the cell was kept in normal saline for $6-7 \mathrm{hr}$ prior to the measurement of the $\mathrm{Ca}^{2+}$ current. The mean $\mathrm{Ca}^{2+}$ current density of the stimulated neuron $(-45.3 \pm 3.7 \mathrm{nA} / \mathrm{nF})$ was not significantly different from that of the contralateral control neuron $(-50.4 \pm 4.5 \mathrm{nA} / \mathrm{nF}, n=$ $5 ; p>0.1$ ). These values are compared to the previous experiment (Fig. 2) where stimulation in normal saline produced a significant 28.7 $\pm 6.3 \%$ reduction in $\mathrm{Ca}^{2+}$ current density $(n=6 ; p<0.01)$. Thus, the long-term reduction in $\mathrm{Ca}^{2+}$ current is $\mathrm{Ca}^{2+}$ dependent. 
A.

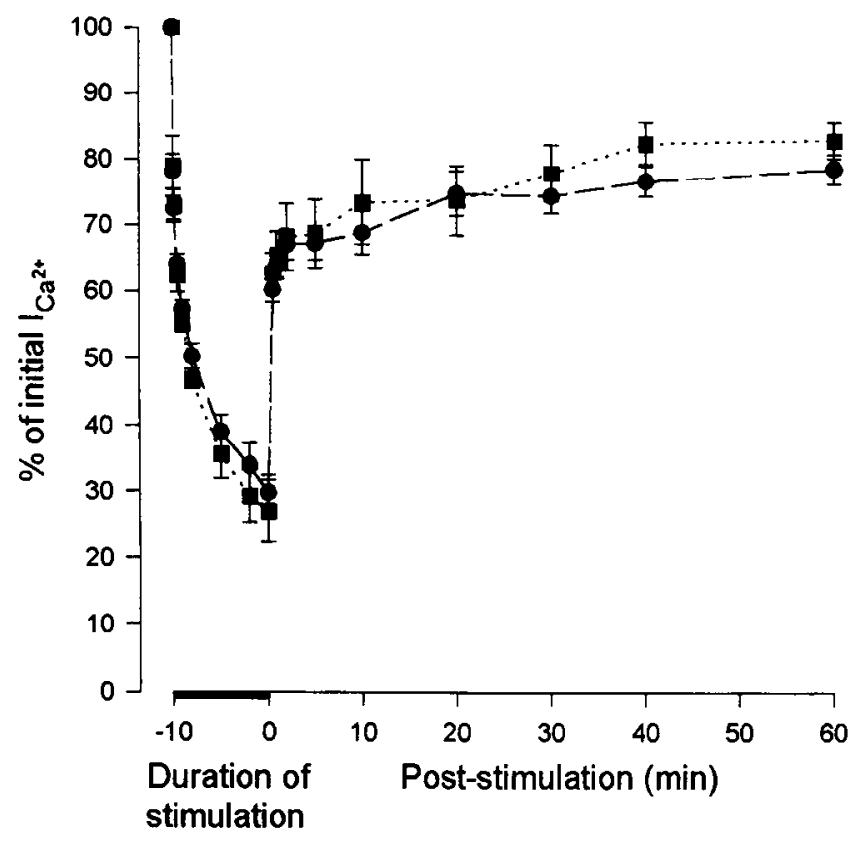

B.

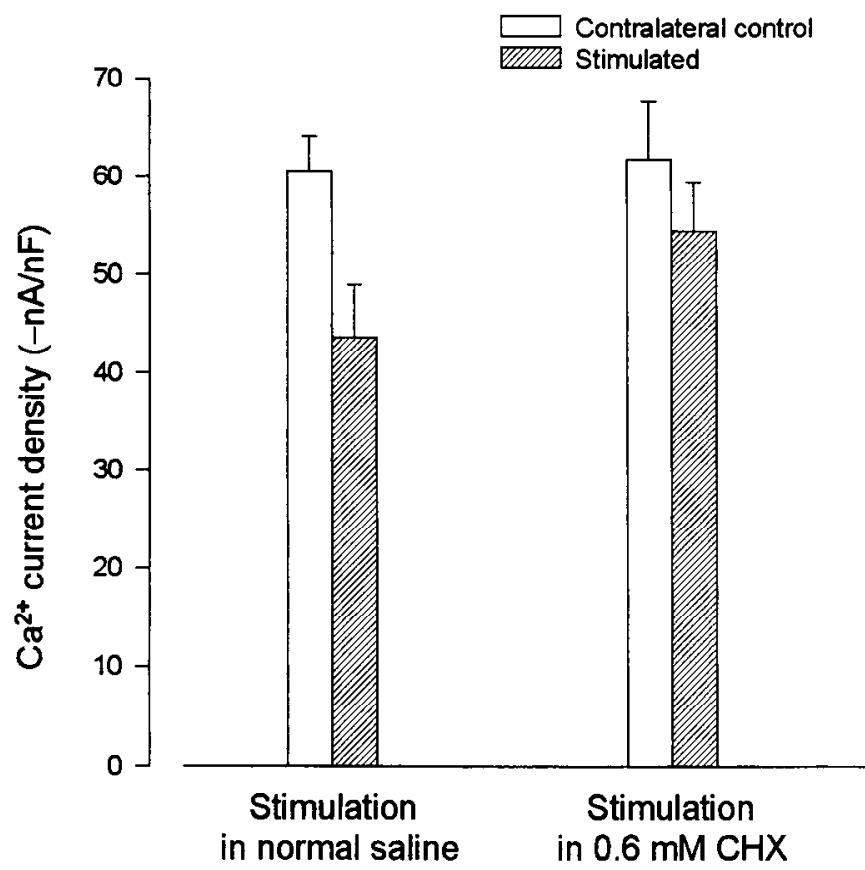

Figure 8. The role of protein synthesis in the short-term and longterm reduction in $\mathrm{Ca}^{2+}$ current. $A$. Effect of inhibition of protein synthesis upon the short-term reduction in $\mathrm{Ca}^{2+}$ current. To examine the effect of protein synthesis on the short-term reduction in $\mathrm{Ca}^{2+}$ current, protein synthesis was blocked by applying $0.6 \mathrm{~mm} \mathrm{CHX} \mathrm{to} \mathrm{the} \mathrm{bath} 4-$ $5 \mathrm{hr}$ before stimulation. The $\mathrm{r} 3 \mathrm{cell}$ body was stimulated with $50 \mathrm{msec}$ depolarizing pulses to $0 \mathrm{mV}$ at $1 \mathrm{~Hz}$ for $10 \mathrm{~min}$ in $2 \times$ normal $\mathrm{Ca}^{2+}$ concentration. During stimulation, the short-term reduction in $\mathrm{Ca}^{2+}$ was not significantly different in cells stimulated in the presence $(\square)$ and in the absence of CHX (O). One hour after stimulation, the decrease in the $\mathrm{Ca}^{2+}$ current amplitude in cells stimulated in the presence of the inhibitor $(17.0 \pm 2.8 \%, n=5)$ was not significantly different from cells stimulated without the inhibitor $(21.9 \pm 2.6 \%, n=6 ; p>0.1)$. effect upon the short-term reduction in $\mathrm{Ca}^{2+}$ current or the persistent reduction in $\mathrm{Ca}^{2+}$ current observed $1 \mathrm{hr}$ after stimulation (Fig. 8A). The reduction in $\mathrm{Ca}$ current during stimulation and the immediate recovery at the end of stimulation was similar in the absence and presence of the protein synthesis inhibitor. The persistent reduction in the $\mathrm{Ca}^{2+}$ current observed $1 \mathrm{hr}$ poststimulation was not significantly different in cells stimulated in the presence $(17.0 \pm 2.8 \%, n-5)$ or absence $(21.3 \pm 2.2 \%, n-$ $6 ; t$ test, $p>0.05$ ) of the protein synthesis inhibitor.

To test the effect of inhibiting protein synthesis upon the longterm reduction in $\mathrm{Ca}^{2+}$ current, the axon was stimulated in vitro at $5 \mathrm{~Hz}$ for $45 \mathrm{~min}$ as in the previous experiments (Fig. 1) and the $\mathrm{Ca}^{2+}$ currents were measured 6-7 hr later. After stimulation, CHX was washed out and the motoneuron was maintained in normal saline for 6-7 hr. The peak $\mathrm{Ca}^{2+}$ current amplitude was then measured in the stimulated and contralateral control cells (Fig. 8B). The mean density of the $\mathrm{Ca}^{2+}$ current in the stimulated cells $(-54.5 \pm 5.0 \mathrm{nA} / \mathrm{nF})$ was not significantly different from the contralateral control cells $(-61.9 \pm 5.8 \mathrm{nA} / \mathrm{nF}, n=8 ; p>$ $0.1)$. In addition, the reduction in the $\mathrm{Ca}^{2+}$ current density $(9.4$ $\pm 5.3 \%$ ) observed in the presence of $\mathrm{CHX}$ was significantly different from that $(28.7 \pm 6.3 \% ; t$ test, $p<0.05)$ observed in cells stimulated in normal saline. These results demonstrate that inhibition of protein synthesis prevents the full expression of the activity-dependent reduction in $\mathrm{Ca}^{2+}$ current observed 6-7 $\mathrm{hr}$ after stimulation.

\section{Discussion}

Short-term reduction in voltage-dependent $\mathrm{Ca}^{2+}$ current

We observed a short-term, $\mathrm{Ca}^{2+}$-dependent reduction in $\mathrm{Ca}^{2+}$ current during the application of repetitive depolarizing pulses to the cell body of a crayfish motoneuron. There is a progressive reduction in $\mathrm{Ca}^{2+}$ current during repetitive stimulation followed by a rapid partial recovery of the $\mathrm{Ca}^{2+}$ current at the end of stimulation. Paired-pulse studies show that these $\mathrm{Ca}^{2+}$ channels undergo a $\mathrm{Ca}^{2+}$-dependent inactivation similar to that previously described in a broad range of cell types (for review see Eckert and Chad, 1984; Chad, 1989). It appears likely that the progressive reduction in $\mathrm{Ca}^{2+}$ current observed during repetitive stimulation is duc to accumulation of intraccllular $\mathrm{Ca}^{2+}$ resulting in increasing $\mathrm{Ca}^{2+}$-dependent $\mathrm{Ca}^{2+}$ channel inactivation.

Calcium-dependent inactivation of $\mathrm{Ca}^{2+}$ channels results from a decrease in the probability of $\mathrm{Ca}^{2+}$ channel opening (Lux and Brown, 1984). The rapid kinetics of $\mathrm{Ca}^{2+}$ channel inactivation suggest that $\mathrm{Ca}^{2+}$ produces inactivation by binding to a site at or near the mouth of the $\mathrm{Ca}^{2+}$ channel (Fryer and Zucker, 1993;

\section{$\leftarrow$}

$B$, To determine if protein synthesis plays a role in the long-term reduction in $\mathrm{Ca}^{2+}$ current observed 6-7 hr after stimulation, protein synthesis was blocked by applying $0.6 \mathrm{~mm} \mathrm{CHX}$ to the bath $45 \mathrm{hr}$ before stimulation. The motoneuron was stimulated with a suction electrode applied to the axon as previously described (Fig. 1). Suprathreshold stimulation of the axon was perlormed at $5 \mathrm{H} /$ for 45 min. Six to seven hours after stimulation, the mean density of $\mathrm{Ca}^{2+}$ currents in the stimulated cell $(-54.5 \pm 5.0 \mathrm{nA} / \mathrm{nF})$ was not significantly different from the contralateral control cell $(-61.9 \pm 5.8 \mathrm{nA} / \mathrm{nF}, n=8 ; p>0.1)$. These values are compared to measurements from the previous experiment performed in normal saline. The reduction in $\mathrm{Ca}^{2+}$ current $(9.4$ $\pm 5.3 \%$ ) observed when protein synthesis was blocked is significantly different from that observed in cells stimulated in normal saline (28.7 $\pm 6.3 \%, n=6 ; t$ test, $p<0.05$ ). These results demonstrate that protein synthesis is required for full expression of the long-term, activity-dependent reduction in $\mathrm{Ca}^{2+}$ currents. 
Johnson and Byerly, 1993b). It has been proposed that the $\mathrm{Ca}^{2+}$ dependent inactivation of $\mathrm{Ca}^{2+}$ channels found in Helix neurons is produced by activation of a $\mathrm{Ca}^{2+}$-dependent phosphatase such as calcineurin, and subsequent dephosphorylation of the $\mathrm{Ca}^{2+}$ channel (Chad and Eckert, 1986). Alternatively, more recent evidence in Lymnaea neurons suggests that $\mathrm{Ca}^{2+}$-dependent disruption of the cytoskeleton could play a role in $\mathrm{Ca}^{2+}$ channel inactivation (Johnson and Byerly, 1993a).

The initial rapid recovery of the $\mathrm{Ca}^{2+}$ current at the end of repetitive stimulation is followed by a slower recovery phase. One hour after the $10 \mathrm{~min}$ stimulation period, a persistent reduction in $\mathrm{Ca}^{2+}$ current can still be observed. This persistent reduction is $\mathrm{Ca}^{2+}$ dependent and can be eliminated under conditions in which $\mathrm{Ca}^{2+}$ influx is reduced. It is presently unclear whether the mechanisms of this change are similar to the shortterm effect or the long-term change discussed below.

\section{Long-term reduction in voltage-dependent $\mathrm{Ca}^{2+}$ current}

We have observed a long-term, activity-dependent reduction in $\mathrm{Ca}^{2+}$ current 6-7 hr and $3 \mathrm{~d}$ after a single stimulation period. It appears likely that this long-term reduction in $\mathrm{Ca}^{2+}$ current persists for more than $3 \mathrm{~d}$ since the magnitude of the reduction in $\mathrm{Ca}^{2+}$ current observed 6-7 hr after stimulation shows little attenuation after $3 \mathrm{~d}$. Similar to the short-term $\mathrm{Ca}^{2+}$ channel inactivation, the long-term effect is also $\mathrm{Ca}^{2+}$ dependent. The reduction in $\mathrm{Ca}^{2+}$ current observed 6-7 hr after stimulation is prevented by blocking $\mathrm{Ca}^{2+}$ influx during stimulation. In addition, the short-term and long-term changes appear to involve the same species of $\mathrm{Ca}^{2+}$ channel. Application of $\mathrm{Ca}^{2+}$ channel blockers indicates that the cell body contains a single type of $\mathrm{Ca}^{2+}$ channel, or at least is dominated by a single channel type (Hong and Lnenicka, unpublished observations). The shape of the $I-V$ curve and the decay of the $\mathrm{Ca}^{2+}$ current remain the same after the reduction in $\mathrm{Ca}^{2+}$ current density, providing further evidence that a single species of $\mathrm{Ca}^{2+}$ channel is involved.

The mechanisms underlying the short-term and long-term reduction in $\mathrm{Ca}^{2+}$ current differ in their sensitivity to inhibitors of protein synthesis. Application of $\mathrm{CHX}$ before stimulation attenuates the long-term reduction $\left(6-7 \mathrm{hr}\right.$ poststimulation) in $\mathrm{Ca}^{2+}$ current, but has no effect upon the short term reduction in $\mathrm{Ca}^{2+}$ current. Interestingly, the persistent reduction in $\mathrm{Ca}^{2+}$ current observed $1 \mathrm{hr}$ after stimulation is also not affected by inhibition of protein synthesis, indicating that it probably results from a different mechanism than the long-term reduction. In addition, it appears that the long-term reduction in $\mathrm{Ca}^{2+}$ current is not confined to the site of $\mathrm{Ca}^{2+}$ influx, but occurs more globally. During stimulation of the axon, the cell body is no longer excitable after the first few action potentials. Based upon the characteristics of the $I-V$ curve for the $\mathrm{Ca}^{2+}$ current, the remaining electrotonic depolarization of the cell body is unlikely to produce significant $\mathrm{Ca}^{2+}$ influx. Thus, it appears that the $\mathrm{Ca}^{2+}$ influx at remote sites produces changes in $\mathrm{Ca}^{2+}$ channels at the cell body.

We do not know whether the long-term reduction in $\mathrm{Ca}^{2+}$ current density results from a change in the properties of individual channels, that is, decreased unitary conductance or probability of opening, or a decrease in the number of functional channels. The lack of change in $\mathrm{Ca}^{2+}$ current kinetics and in the $I-V$ curve argues against a change in the properties of individual channels. A reduction in the number of $\mathrm{Ca}^{2+}$ channels is supported by earlier findings. Chronic depolarization of $\mathrm{PCl} 2$ cells produced by elevated potassium concentrations results in a re- duction of the number of dihydropyridine-sensitive $\mathrm{Ca}^{2+}$ channels, as determined by binding studies (DeLorme and McGee, 1986; DeLorme et al., 1988). This $\mathrm{Ca}^{2+}$-dependent effect has a slow onset: no reduction is observed after $4 \mathrm{hr}$ of constant depolarization, a $30 \%$ reduction occurs after $1 \mathrm{~d}$ of depolarization, and a maximum $50 \%$ reduction is seen after $3 \mathrm{~d}$ of constant depolarization (DeLorme et al., 1988).

$A$ reduction in the number of functional $\mathrm{Ca}^{2+}$ channels could result from increased degradation or decreased synthesis of $\mathrm{Ca}^{2+}$ channel proteins. The latter appears unlikely since a previous study of cultured myenteric neurons found that $\mathrm{CHX}$ treatment for $24 \mathrm{hr}$ did not reduce $\mathrm{Ca}^{2+}$ channel density (Franklin et al., 1992). This previous study also showed that inhibition of protein synthesis reduced the depolarization-induced decrease in the sustained component of the $\mathrm{Ca}^{2}$ current. Consistent with these results, we found that blocking protein synthesis attenuates the long-term reduction in $\mathrm{Ca}^{2+}$ current. The effect of inhibition of protein synthesis suggests that (1) $\mathrm{Ca}^{2+}$ influx produces an increase in the production of proteins involved in degrading or modifying $\mathrm{Ca}^{2+}$ channels, or (2) $\mathrm{Ca}^{2+}$-dependent pathways that are involved in degrading or modifying $\mathrm{Ca}^{2+}$ channels include short-lived proteins, which are rapidly depleted. The latter hypothesis is consistent with the effects of protein synthesis inhibitors upon the long-term, activity-dependent reduction in transmitter release from crustacean motor terminals (Nguyen and Atwood, 1990).

Calcium-activated proteases could be involved in this longterm reduction in $\mathrm{Ca}^{2+}$ current. The "washout" of $\mathrm{Ca}^{2+}$ currents observed in dialyzed cells includes an irreversible component, which is $\mathrm{Ca}^{2+}$ dependent (Chad and Eckert, 1986). Since this component is blucked by the $\mathrm{Ca}^{2+}$-dependent protease inhibitor leupeptin, it has been proposed that the irreversible washout is produced by $\mathrm{Ca}^{2+}$-dependent proteolysis. In addition, the $\mathrm{Ca}^{2+}$ dependent protease calpain has been shown to produce an irreversible reduction in $\mathrm{Ca}^{2+}$ currents in guinea pig myocytes (Belles et al., 1988). $\mathrm{Ca}^{2+}$-activated proteases may irreversibly activate phosphatases (Manalan and Klee, 1983; Tallant et al., 1988 ) that inactivate the $\mathrm{Ca}^{2+}$ channel through dephosphorylation (Chad and Eckert, 1986; for review see Armstrong, 1989).

\section{Significance for cellular and synaptic physiology}

The $\mathrm{Ca}^{2+}$-dependent reduction in $\mathrm{Ca}^{2+}$ current is presumably an important mechanism for adjusting $\mathrm{Ca}^{2+}$ influx to prevent excessively high levels of intracellular $\mathrm{Ca}^{2+}$. It is well established that extremely high intracellular $\mathrm{Ca}^{2+}$ concentrations can produce cytotoxicity (Choi, 1988). In addition, activity-dependent changes in $\mathrm{Ca}^{2+}$ current could modify the intrinsic electrical properties of neurons, as well as directly alter transmitter release. Calcium-dependent changes in ionic conductances may play an important role in determining the firing properties of neurons (LeMasson et al., 1993; Turrigiano et al., 1994).

The activity-dependent reduction in $\mathrm{Ca}^{2+}$ current may play a role in changes in transmitter release from crustacean motor terminals. The short-term inactivation of $\mathrm{Ca}^{2+}$ currents during repetitive stimulation of the phasic motoneuron could contribute to the prominent synaptic depression observed at the neuromuscular synapses of these motoneurons. In Aplysia, it has been proposed that $\mathrm{Ca}^{2+}$ channel inactivation is responsible for synaptic depression and the resulting short-term habituation (Klein et al., 1980). At crustacean neuromuscular synapses, a chronic increase in impulse activity produces a long-term reduction in initial transmitter release (Lnenicka and Atwood, 1985; Mercier 
and Atwood, 1989; Bradacs ct al, 1990), whcrcas a chronic decrease in impulse activity produces a long-term reduction in initial transmitter release (Pahapill et al., 1985). Similar activitydependent changes in initial transmitter release have been shown at vertebrate central (Gallego et al., 1979; Gallego and Geijo, 1987; Manabe et al., 1990) and peripheral synapses (Robbins and Fischbach, 1971; Snider and Harris, 1979; Hinz and Wernig, 1988). We have recently shown in the crayfish that the longterm, activity-dependent decrease in transmitter release is triggered by $\mathrm{Ca}^{2+}$ influx (Hong and Lnenicka, 1993a).

Since both the long-term, activity-dependent reduction in $\mathrm{Ca}^{2+}$ current and transmitter release observed in this crayfish motoneuron are $\mathrm{Ca}^{2+}$ dependent, it is reasonable to hypothesize that the reduction in transmitter release is due to a reduction in $\mathrm{Ca}^{2+}$ current. Since the $\mathrm{Ca}^{2+}$ currents were measured in the cell body, we have no direct evidence that $\mathrm{Ca}^{2+}$ currents at the motor terminals undergo an activity-dependent reduction. However, there are parallels between the two effects. The activity-dependent reduction in the voltage-dependent $\mathrm{Ca}^{2+}$ current is sensitive to inhibition of protein synthesis in a manner consistent with the activity-dependent reduction in transmitter release (Nguyen and Atwood, 1990). In addition, a reduction in transmitter release from motor terminals can be produced by calcium influx at the cell body (Hong and Lnenicka, 1993a). Similarly, it appears that $\mathrm{Ca}^{2+}$ influx in a separate region of the motoneuron can reduce the currents produced by $\mathrm{Ca}^{2+}$ channels at the cell body.

\section{References}

Armstrong DL (1989) Calcium channel regulation by calcineurin, a $\mathrm{Ca}^{2+}$-activated phosphatase in mammalian brain. Trends Neurosci 12: $117-122$.

Belles B, Hescheler J, Blomgren W, Karlsson JO (1988) A possible physiological role of $\mathrm{Ca}$-dependent protease calpain and its inhibitor calpastatin on the Ca current in guinea-pig myocytes. Pfluegers Arch 412:554-556.

Berdan RC, Easaw JC, Wang R (1993) Alterations in membrane potential after axotomy at different distances from the soma of an identified neuron and the effect of depolarization on neurite outgrowth and calcium channel expression. J Neurophysiol 69:151-164.

Bradacs H, Mercier AJ, Atwood HL (1990) Long-term adaptation in lobster motor neurons and compensation of transmitter release by synergistic inputs. Neurosci Lett 108:110-115.

Brehm E, Eckert R (1978) Calcium entry leads to inactivation of calcium current in Paramecium. Science 202:1203-1206.

Chad J (1989) Inactivation of calcium channels. Comp Biochem Physiol 3A:95-105.

Chad JE, Eckert R (1986) An enzymatic mechanism for calcium current inactivation in dialyzed Helix neurones. J Physiol (Lond) 378: $31-5 \mathrm{I}$.

Choi DW (1988) Calcium-mediated neurotoxicity: relationship to specific channel types and role in ischemic damage. Trends Neurosci 11: $465-469$

DeLorme EM. McGee R Jr (1986) Regulation of voltage dependent $\mathrm{Ca}^{2+}$ channels of neuronal cells by chronic changes in membrane potential. Brain Res 397:189-192.

DeLorme EM, Rabe CS, McGee R Jr (1988) Regulation of the number of functional voltage-sensitive $\mathrm{Ca}^{2+}$ channels on $\mathrm{PC} 12$ cells by chronic changes in membrane potential. J Pharmacol Exp Ther 244:838843.

Eckert R, Chad JE (1984) Inactivation of calcium channels. Prog Biophys Mol Biol 44:215-267.

Eckert R, Tillotson DL (1981) Calcium-mediated inactivation of the calcium conductance in caesium-loaded giant neurones of Aplysia california. J Physiol (Lond) 314:265-280.

Franklin JL, Fickbohm DJ, Willard AL (1992) Long-term regulation of neuronal calcium currents by prolonged changes of membrane potential. J Neurosci 12:1726-1735.

Fryer MW, Zucker RS (1993) $\mathrm{Ca}^{2+}$-dependent inactivation of $\mathrm{Ca}^{2+}$ cur- rent in Aplysia neurons: kinetic studies using photolabile $\mathrm{Ca}^{2+}$ chelators. J Physiol (Lond) 464:501-528.

Gallego R, Geijo E (1987) Chronic block of the cervical trunk increases synaptic efficacy in the supcrior and stellate ganglia of the guineapig. J Physiol (Lond) 382:449-462.

Gallego R, Kuno M, Nunez R, Snider WD (1979) Disuse enhances synaptic efficacy in spinal motoneurones. J Physiol (Lond) 291:191205.

Gutnick MJ, Lux HD, Swandulla D, Zucker H (1989) Voltage-dependent and calcium-dependent inactivation of calcium channel current in identified snail neurones. J Physiol (Lond) 412:197-220.

Hinz I, Wernig A (1988) Prolonged nerve stimulation causes changes in transmitter release at the frog neuromuscular junction. J Physiol (Lond) 401:557-565.

Hong SJ, Lnenicka GA (1993a) Long-term changes in the neuromuscular synapses of a crayfish motoneuron produced by calcium influx. Brain Res 605:121-127.

Hong SJ, Lnenicka GA (1993b) Activity-dependent changes in voltage-sensitive calcium currents. Soc Neurosci Abstr 19:1756.

Johnson BD, Byerly L (1993a) A cytoskeletal mechanism for $\mathrm{Ca}^{2+}$ channel metabolic dependence and inactivation by intracellular $\mathrm{Ca}^{2}$. Neuron 10:797-804

Johnson BD, Byerly L (1993b) Photo-released intracellular $\mathrm{Ca}^{2+}$ rapidly blocks $\mathrm{Ba}^{2+}$ current in Lymnaea neurons. J Physiol (Lond) 462 : 321-347.

Kay AR, Wong RKS (1987) Calcium current activation kinetics in isolated pyramidal neurons of the CA1 region of the mature guineapig hippocampus. J Physiol (Lond) 392:603-616.

Klein M, Shapiro E, Kandel ER (1980) Synaptic plasticity and the modulation of the $\mathrm{Ca}^{2+}$ current. J Exp Biol 89:117-157.

LeMasson G, Marder E, Abbott LF (1993) Activity-dependent regulation of conductances in model neurons. Science 259:1915-1917.

Lnenicka GA (1991) The role of activity in the development of phasic and tonic synaptic terminals. Ann NY Acad Sci 627:197-211.

Lnenicka GA, Atwood HL (1985) Age-dependent long-term adaptation of crayfish phasic motor axon synapses to altered activity. J Neurosci $5: 459-467$.

Lux HD, Brown AM (1984) Single channel studies on inactivation of calcium currents. Science 225:432-434.

Manabe T, Kaneko CRS, Kuno M (1990) Disuse-induced enhancement of $I_{\mathrm{a}}$ synaptic transmission in spinal motoneurons of the rat. J Neurosci 9:2455-2461.

Manalan AS, Klee CB (1983) Activation of calcineurin by limited proteolysis. Proc Natl Acad Sci 80:4291-4295.

Mercier AJ, Atwood HL (1990) Long-term adaptation of a phasic extensor motoneurone in crayfish. $J$ Exp Biol 145:9-22.

Nguyen PV, Atwood HL (1990) Expression of long-term adaptation of synaptic transmission requires a critical period of protein synthesis. J Neurosci 10:1099-1109.

Pahapill PA, Lnenicka GA, Atwood HL (1985) Asymmetry of motor impulses and neuromuscular synapses produced in crayfish claws by unilateral immobilization. J Comp Physiol 157:461-467.

Rayner M, Wiersma CAG (1965) Functional aspects of the anatomy of the thoracic and abdominal flexor musculature of the crayfish Procambarus clarkii (Girard). Am Zool 4:285.

Robbins N, Fischbach GD (1971) Effect of chronic disuse of rat soleus neuromuscular junctions on presynaptic function. J Neurophysiol 34: $570-578$.

Snider WD, Harris GL (1979) Physiological correlate of disuse-induced sprouting at the neuromuscular junction. Nature 281:69-71.

Tallant EA, Brumley LM, Wallace RW (1988) Activation of a calmodulin-dependent phosphatase by a $\mathrm{Ca}^{2+}$-dependent protease. Biochemistry 27:2205-2211.

Tillotson D (1979) Inactivation of Ca conductance dependent on entry of $\mathrm{Ca}$ ions in molluscan neurons. Proc Natl Acad Sci 76:1497-1500.

Turrigiano G, Abbott LF, Marder E (1994) Activity-dependent changes in the intrinsic properties of cultured neurons. Science 264:974-977.

Van Harreveld A (1936) A physiological solution for freshwater crustaceans. Proc Soc Exp Biol Med 34:428-432.

Wettstein FO, Noll H, Penman S (1964) Effect of cycloheximide on ribosomal aggregates engaged in protein synthesis in vitro. Biochim Biophys Acta 87:525-528.

William PT, Pittman QJ, MacVicar BA (1991) $\mathrm{Ca}^{2+}$ - and voltage-dependent inactivation of $\mathrm{Ca}^{2+}$ currents in rat intermediate pituitary. Brain Res 564:12-18. 